\title{
Amelioration of Hepato-Renal Toxicity by a Flavonoid-Rich Fraction of Hibiscus rosa-sinenses (Leaves and Flowers) in Male Rabbits Intoxicated by Cadmium
}

\author{
Naqi Hussain ${ }^{1 *}$, Muhammad Nawaz Chaudhary , Aftab Ahmed Anjum², \\ Naeem Abbas ${ }^{3}$, Muhammad Zaheer ${ }^{4}$, Ghulam Mustafa ${ }^{5}$, Muzaffar Majid ${ }^{1}$ \\ ${ }^{1}$ College of Earth and Environmental Sciences, University of the Punjab, Lahore, Pakistan \\ ${ }^{2}$ Department of Microbiology, University of Veterinary and Animal Sciences, Lahore, Pakistan \\ ${ }^{3}$ Centre of Environmental Protection Studies, Pakistan Council of Scientific and Industrial Research, \\ Lahore, Pakistan \\ ${ }^{4}$ Applied Chemistry Research Centre, Pakistan Council of Scientific and Industrial Research, Lahore, Pakistan \\ ${ }^{5}$ Quality Operations Laboratory, University of Veterinary and Animal Sciences, Lahore, Pakistan
}

Received: 9 January 2017

Accepted: 8 February 2017

\begin{abstract}
This study was initiated to anticipate the potential protective effects of flavonoid-rich fractions of Hibiscus rosa-sinenses flowers (HF) and leaves (HL) on cadmium (Cd)-induced toxicity in adult albino rabbits. $\mathrm{Cd}$, being a prominent environmental pollutant, poses a threat for its widespread range of toxic expressions. A dramatic increase in total phenolics, flavonoids, and antioxidant capacity has been observed in flavonoid-rich fractions of $\mathrm{HF}$ and $\mathrm{HL}$ as compared to their crude extracts, suggesting for the rationale for their use in this study. Thirty-six male rabbits were indiscriminately allocated into six groups, including control, Cd (6.1 mg Cd/kg/day), HF and HL (200 mg HF \& HL / Kg/day), Cd+HF, and Cd+HL (receiving the same doses of Cd, HF, and HL) groups. Treatment (p.o) for 60 days resulted in improvement of weight gain in $\mathrm{Cd}+\mathrm{HF}$ and $\mathrm{Cd}+\mathrm{HL}$ groups in comparison with the $\mathrm{Cd}$ group. Treatment with $\mathrm{Cd}+\mathrm{HF}$ showed better results than $\mathrm{Cd}+\mathrm{HL}$ by significantly decreasing $(\mathrm{p}<0.05)$ transaminases $(\mathrm{AST}, \mathrm{ALT})$, alkaline phosphatase (ALP), gamma glutamyl transferase (GGT), and creatinine and urea levels, while total bilirubin and albumin were increased on the $15^{\text {th }}, 30^{\text {th }}, 45^{\text {th }}$, and $60^{\text {th }}$ days in a progressive manner when compared with the $\mathrm{Cd}$ receiving group. Likewise, the $\mathrm{Cd}+\mathrm{HF}$ group showed better activities than $\mathrm{Cd}+\mathrm{HL}$ by significantly increasing $(\mathrm{p}<0.05)$ superoxide dismutase, catalase, and vitamins $\mathrm{C}$ and $\mathrm{E}$, while LPO and Cd concentrations were significantly decreased in the liver and kidney tissues when compared with Cd-intoxicated bucks. Values of these parameters in only HF and HL-receiving groups were near the control. The histopathological
\end{abstract}

*e-mail: syed_naqi@hotmail.com 
studies for these tissues have also sustained the above-mentioned data. Thus, these outcomes suggest that the flavonoid-rich fraction of HF may act as a potent hepatic and renal protective agent than HL against Cd-induced toxicity in animal models.

Keywords: cadmium toxicity, antioxidant, transaminases, hepato-renal toxicity, histopathological studies

\section{Introduction}

It is apparent that increasingly anthropogenic activities have modified the cycle of heavy metals and metalloids globally, including toxic elements like Cd. Thus a plentiful prospect for exposure to $\mathrm{Cd}$ is possible in and outside the workplace [1]. Concentrations of $\mathrm{Cd}$ in an adjacent environment is cumulative owing to its miscellaneous sources and very long biological half-life ranging from 10 to 30 years. $\mathrm{Cd}$ in biological systems is dispensable and it is known to be toxic even at low concentrations [2-3]. Cadmium exposure (acute and chronic) in plants, animals, and humans may cause harm to various organs, including the brain, gastro-intestinal tract, liver, lungs, and testes. Many related disorders include renal dysfunction, hepatotoxicity, anemia, osteoporosis, DNA damage, neurodegenerative diseases, and immunosuppressive and proinflammatory effects [3-6]. A number of mechanisms have been proposed to explain the damage induced by $\mathrm{Cd}$, but it is not yet well understood, although some experimental evidence can determine that deleterious effects of cadmium are due to oxidative stress by depletion of the endogenous antioxidants that serve as a premier source of protection against free radicals and other oxidative stressors. Conventionally, ethno medicines are being used widely in the sub-continent and elsewhere generally owing to their low cost, easy accessibility, and apparentlt reduced side effects [3]. The mechanism of action of these herbal remedies is diverse in many respects from that of the synthetic drugs/pure compounds. This effect may be regarded as polyvalent action and understood as an additive.

The $H$. rosa-sinensis L. (family Malvaceae) evergreen medicinal shrub is commonly used in conventional medicine (red-flowered variety) as an antidiabetic and for gastrointestinal disorders, and for its cardioprotective, anticarcinogenic, antioxidative, renoprotective, hepatopretective, neuroprotective, and anti-inflammmatory properties, and for managing cognitive disorders [7-11]. The phytochemicals reported so far in Hibiscus rosa sinensis L. include alkaloids, amino acids, anthrocyanins, carbohydrate, flavonoids, glycosides, phytosterols, polyphenols, and vitamins [7, 12-13]. The promising protective activity of $H$. rosasinensis flavonoid-rich fractions, leaves, and flowers against $\mathrm{Cd}$-induced renal and hepatotoxicity has not been reported so far. Therefore, this study aims to evaluate the potential defensive effects of the $H$. rosa-sinensis by using the $\mathrm{Cd}$-induced sub-chronic oxidative hepato-renal injury model in male rabbits.

\section{Materials and Methods}

\section{Collection, Identification and Extraction of Plant Material}

Fresh leaves and mature flowers of Hibiscus rosasinensis Linn (red-flowered variety) were collected from the Botanical Garden of the University of Punjab, Lahore, during July-August 2016. Identification and authentication were performed by the Department of botany, GC University, Lahore. The plant material was also duly identified by Prof. Dr. Abdul Nasir Khalid, the in-charge herbarium and senior taxonomist for the Department of Botany at the University of the Punjab, Lahore-Pakistan. Fresh leaves and mature flowers were washed with distilled water, air-dried, and finely ground and extracted with ethanol $(1: 20 \mathrm{w} / \mathrm{v})$ using an ultrasonic bath for six hrs at room temp. After filtration through Wattman filter paper No. 1 it was evaporated to dryness at $40^{\circ} \mathrm{C}$ using a rotary evaporator (Edolph Rotary, Germany) at PCSIR Laboratories Complex, Lahore. Extraction was carried out in triplicate to increase the percentage yield of extracts. Then crude extracts of flowers and leaves were suspended in double-distilled $\mathrm{H}_{2} \mathrm{O}$, then partitioned successively with pet-ether and ethyl acetate (EtOAc), and both fractions were evaporated to dryness using a rotary evaporator, then obtained EtOAc fraction was dissolved in ethanol $(\mathrm{etOH})$ and precipitation was achieved, in EtOAc fraction, by treating this fraction with neutral lead acetate. These precipitates were centrifuged, re-suspended in etOH, treated with $\mathrm{H}_{2} \mathrm{~S}$, and filtered to harvest the flavonoid-rich fraction by evaporation according to the method of [14]. These EtOAc fractions were preferably selected, out of crude extracts and pet ether fractions, due to their more phenolic and flavonoid contents and high antioxidant potential. These fractions were retained in glass bottles, covered with aluminum foil, and kept in a refrigerator until further use.

\section{In-vitro Determination of Total Phenolic, Flavonoids and Antioxidant Contents}

The total phenolic and flavonoid contents of crude extracts and flavonoid-rich fractions were determined, based on Folin-Ciocalteu's reagent and the aluminum chloride method, respectively, as described by the method of Singleton and [15-16]. Results of total phenolic and flavonoid contents of crude extracts and flavonoids rich fractions were stated as $\mathrm{mg}$ gallic acid equivalents (GAE) and quercetin equivalents (QE) per gram of dry 
weight of sample. Total antioxidant capacity (TAOC) was determined using the phospho-molybdenum method by Prieto et al. [17], and stated as mg BHT equivalents (BHTE) per gram of sample.

\section{Identifying Polyphenolic Compounds}

The flavonoid-rich fraction was analyzed by thin layer chromatography (TLC) for the presence of gallic acid using a mobile phase comprised of toluene:ethyl acetate:formic acid:methanol (3:3:0.8:0.2 v/v), quercetin using toluene:ethyl acetate:formic acid $(5: 4: 1 \mathrm{v} / \mathrm{v})$, and rutin using ethyl acetate:n- butanol:formic acid:water $(5: 3: 1: 1 \mathrm{v} / \mathrm{v})$ at room temperature $\left(25 \pm 2^{\circ} \mathrm{C}\right)$ as described as $[14,18]$

\section{Animals}

Male albino rabbits (Oryctolagus cuniculus), aged between 22-28 weeks and weighing between 1.8-2.4 $\mathrm{Kg}$, bred in the animal house of the Pakistan Council of Scientific and Industrial Research, Lahore-Pakistan were used in this study. Rabbits were offered a routine diet and free access to fresh drinking water. Animals were kept in individual cages and were handled carefully under standard conditions of $12 \mathrm{~h}$ dark light cycle in temperature $24 \pm 3^{\circ} \mathrm{C}$ and relative humidity of 50-60\%. Before commencing this experiment, all animals were injected with $0.1 \mathrm{~mL} / \mathrm{Kg}$ body weight ivermectin (s.c.) [19] to eradicate endo and ecto-parasites, followed by a week of adjustment period. This treatment, with ivermectin, will help to minimize the interference of parasites in the course of the study. The study protocols were approved (dated 18/06/2014) by the Advanced Studies and Research Board of Punjab University, Pakistan. Experimental protocols were in agreement with the NIH guidelines for the care and use of laboratory animals. Measurements of live body weights were recorded carefully, on electronic balance, after every 10 days up to 60 days.

\section{Selection of Cadmium and H. rosa sinensis Dosage}

The $1 / 10^{\text {th }}$ dose of $\mathrm{LD}_{50}$ of $\mathrm{Cd}\left(\right.$ as $\left.\mathrm{CdCl}_{2}\right)$, determined previously as $61.34 \mathrm{mg} / \mathrm{Kg}$ body weight [20], corresponding to $6.1 \mathrm{mg} / \mathrm{Kg}$ body weight, was selected to induce toxicity in male albino rabbits. In order to assess the pertinent dose of ethyl acetate fractions of $H$. rosa sinensis leaves and flowers, three different concentrations, i.e., 50, 100, and $200 \mathrm{mg} / \mathrm{Kg}$ body wt. per day, were given via gastric lavage for 15 days. Various biochemical parameters like creatinine, ALP, ALT, AST, and urea were estimated in serum (data not shown). Results of these diagnostic factors recommend that $200 \mathrm{mg} / \mathrm{Kg}$ body wt. per day was a suitable dose to further conduct this study for a period of 60 days.

\section{Experimental}

The experimental design has been made in agreement with the investigational design of Milton Prabu [1]. Six rabbits were apportioned randomly into six groups. These groups were as follows:

1. Control: non-treated animals only received vehicle (distilled water).

2. Received only leaf extract (HL) at a dose of $200 \mathrm{mg} / \mathrm{Kg} /$ day.

3. Received only flower extract (HF) at a dose of $200 \mathrm{mg} / \mathrm{Kg} /$ day.

4. Received cadmium in normal saline at a dose of $6.1 \mathrm{mg} / \mathrm{Kg} /$ day.

5. Rabbits received $6.1 \mathrm{mg} / \mathrm{Kg} /$ day cadmium and $200 \mathrm{mg} / \mathrm{Kg} /$ day flower extract (HF).

6. Rabbits received $6.1 \mathrm{mg} / \mathrm{Kg} /$ day cadmium and $200 \mathrm{mg} / \mathrm{Kg}$ /day leaf extract (HL).

This experimental study was conducted for 60 days, representing a chronic model according to Bae, et al. [21]. All the doses were administered per oral.

\section{Blood and Tissue Sampling}

The day before the initiation of the experiment and after every fifteenth day, $5 \mathrm{ml}$ of blood was collected from the marginal ear vein of each rabbit from all six groups. Samples were divided into two aliquots, one of $2 \mathrm{ml}$ in EDTA containing a tube for CBC (data not shown) and the other of $3 \mathrm{ml}$ in plain dry vacutainer to separate serum after centrifugation $(1,000 \mathrm{rpm}, 10 \mathrm{~min}$.) for selected biochemical analysis. On the $60^{\text {th }}$ day, we dissected all rabbits from each group to remove liver, kidneys, heart, lungs, brain, stomach, testis, small intestine, skeletal muscle, and the femur bone for analysis of cadmium residue (data not shown). Both kidneys and liver were rinsed with cold normal saline, dried, and weighed individually. Small portions of the left kidney and caudal part of the liver were preserved for histopathological examinations and about one gram of each tissue was minced and homogenized (10 times the weight of tissue) in appropriate buffer ( $\mathrm{pH} 7.4$ ) and cold centrifuged (2,000 g for $10 \mathrm{~min}$ ). The resulting clear supernatant was collected for further estimations.

\section{Estimating Markers of Hepatic and Renal Damage}

The serum hepatic and serum renal markers such as alanine transaminase (ALT), aspartate transaminase (AST), alkaline phosphatase (ALP), $\quad$-glutamyl transferase (GGT), creatinine, urea, albumin, total protein (TP), and total bilirubin were tested using chemistry analyzer (Microlab-300, Merck) according to the standard procedures by using diagnostic kits from Sigma diagnostics (Pvt.) Limited, Pakistan. At the start and after every 
$10^{\text {th }}$ day of experiment, the urine was collected in metabolic cages on a 24-hr basis for each animal from all groups. Levels of creatinine and urea in urine were assessed by spectrophotometric methods using commercial Sigma diagnostic kits, Pakistan.

\section{Determination of Lipid Peroxidation and Cadmium Contents in Tissues}

Lipid peroxidation (LPO) in both kidney and liver tissues was assessed by the thiobarbituric acid reacting substance (TBARS) method of Placer et al. [22] and was stated in terms of the malondialdehyde (MDA) content, which served as the standard of 1,1,3,3-tetraethoxypropane. Samples of tissues, assayed for MDA, were added with 1.0 milli-molar BHT for the purpose of preventing artefactual lipid peroxidation in the course of the boiling step. The kidney and liver samples were oven-dried, weighed, and digested with nitric acid and hypochloric acid to estimate the residual level of Cd by AAS (Perkin Elmer, Analyst $800)$. A calibration curve was constructed with 1,2 , and 3 ppm standards of Cd (Perkin Elmer). For certainty of results bovine liver (NIST: 1577b) was used as certified material.

\section{Determining Antioxidant Enzymes, Vitamin C and $\mathrm{E}$ in Tissues}

The activity of superoxide dismutase (SOD) and catalase (CAT; EC 1.11.1.6) was measured in tissue homogenates by the method of [23-24] and using a spectrophotometer at $560 \mathrm{~nm}$ and $240 \mathrm{~nm}$, respectively. Ascorbic acid and ó-tocopherol (Vitamins C and E) were assayed in homogenates of kidney and liver according to the methods of [25-26].

\section{Histopathological Studies}

A small portion of left kidney and caudal part of the liver were fixed for $24 \mathrm{hrs}$ in buffered formalin (10\%), then washed under tap water for $12 \mathrm{hrs}$, dehydrated by passing through different aqueous ethanol mixtures, being cleaned in xylene, and embedded in soft white paraffin. Thin tissue sections (5-6 $\mu \mathrm{m}$ thick) were prepared by rotary microtome and staining was done with haematoxylin and eosin dye with neutral DPX medium for microscopic observations.

\section{Statistical Analysis}

All the data were stated as mean values with standard deviation ( \pm S.D.) for six rabbits in all groups. The statistical significance was calculated by using two factors of completely randomized design (CRD) using SPSS (version 16.0), and the individual comparisons were obtained by least significant difference (LSD). Values were considered statistically significant when $p<0.05$.

\section{Results and Discussion}

\section{Determination of Total Phenolics, Flavonoids, and Antioxidant Contents}

Bioactive compounds were extracted from leaves and flowers in Aq. methanolic crude extracts, fractions of petroleum ether, and ethyl acetate obtained from sequential partitioning of crude extracts. This study showed variable amounts of extraction yields ( $\mathrm{g} / 100 \mathrm{~g}$ of dry weight), TPC (mg GAE/100g), TFC (mg QE/100g), and TAOC (mg AAE/g) among various fractions of both crude extracts. Yield, TPC, TFC, and TAOC of ethyl acetate fraction of flowers were higher, i.e., $72.36 * \pm 2.6$, $90.5 \pm 4.8,42.2 \pm 2.1$, and $77.8 \pm 1.7$ than ethyl acetate fraction of leaves, i.e., $68.36^{*} \pm 2.6,78.5 \pm 4.8,33.2 \pm 2.1$, and $69.8 \pm 1.7$, respectively, whereas Pet. ether fractions have showed the lowest values when compared to ethyl acetate fractions of both extracts as shown in Table 1. Our findings are in near agreement with [10, 27-29].

The dissimilarities in TPC, TFC, and TAOC values may be attributed to the use of different solvents for fractionation. It has been designated in numerous studies that higher levels of polyphenols may be associated with the use of more polar solvents for extraction [30]. Flavonoids and phenolics are produced as natural secondary

Table 1. Percentage yields, total phenolics, flavonoids, and antioxidant capacity of $H$. rosa-sinensis $L$. flowers and leaf extracts.

\begin{tabular}{|c|c|c|c|c|c|}
\hline \multirow{2}{*}{ Parts used } & $\begin{array}{c}\text { Extract/ } \\
\text { Fraction }\end{array}$ & $\begin{array}{c}\text { Percentage yields } \\
(\mathrm{g} / 100 \mathrm{~g} \text { DW })\end{array}$ & $\begin{array}{c}\text { TPC } \\
(\mathrm{mg} \text { GAE/g DW })\end{array}$ & $\begin{array}{c}\text { TFC } \\
(\mathrm{mg} \text { QE/g DW })\end{array}$ & $\begin{array}{c}\text { TAOC } \\
(\mathrm{mg} \text { BHTE/g DW })\end{array}$ \\
\hline \multirow{3}{*}{ Flower } & Aq. MeOH & $19.31 \pm 2.1$ & $51.30 \pm 2.5$ & $46.51 \pm 1.5$ & $37 \pm 1.9$ \\
\cline { 2 - 6 } & Pet. Ether & $13.48^{*} \pm 0.9$ & $7.8 \pm 0.7$ & $3.2 \pm 0.4$ & $8.2 \pm 0.3$ \\
\cline { 2 - 6 } & EtOAc & $72.36^{*} \pm 2.8$ & $90.56 \pm 5.1$ & $62.21 \pm 2.2$ & $77 \pm 2.9$ \\
\hline \multirow{3}{*}{ Leaves } & Aq. MeOH & $15 \pm 2.2$ & $39.64 \pm 1.5$ & $38.90 \pm 1.2$ & $32 \pm 1.6$ \\
\cline { 2 - 6 } & Pet. Ether & $14.28^{*} \pm 0.8$ & $4.3 \pm 0.5$ & $2.8 \pm 0.3$ & $6.5 \pm 0.2$ \\
\cline { 2 - 6 } & EtOAc & $66.16^{*} \pm 2.6$ & $78 \pm 3.6$ & $53 \pm 1.8$ & $69 \pm 3.2$ \\
\hline
\end{tabular}

*weight of fraction/weight of crude extract 100

Data are presented as means \pm standard deviation $(n=3)$; GAE: Gallic acid equivalents; QE: quercetin equivalents; BHTE: butylated hyhroxy toluene equivalents; DW: dry weight; Aq. MeOH: aqueous methanol; EtOAc: ethyl acetate 


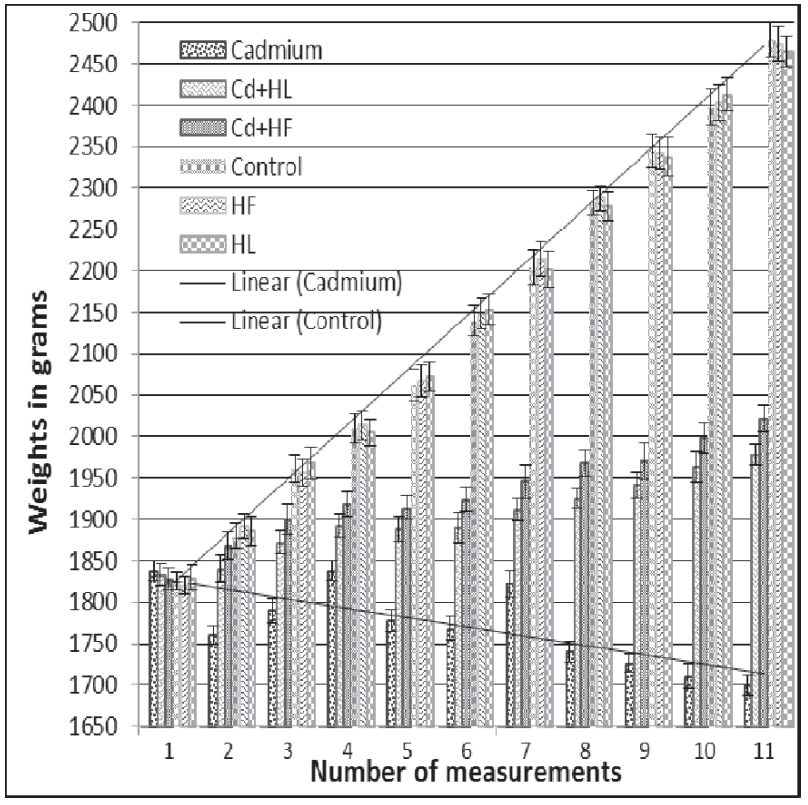

Fig. 1. Variations of body weights in albino rabbits treated subchronically with $\mathrm{Cd}, \mathrm{Cd}+\mathrm{HL}, \mathrm{Cd}+\mathrm{HF}$, control, $\mathrm{HF}$, and $\mathrm{HL}$ from the start to day 60 .

metabolites and possess rich antioxidant properties. These are capable of interacting and scavenging free radicals, which primarily impair cells and may result in the genesis of various diseases. Our results clearly illustrate that phenolic and flavonoid compounds like quercetin and rutin (identified by TLC) are most probably the major contributors to the observed higher antioxidant properties and subsequently result in the prevention of hepato-renal tissues of Cd-intoxicated rabbits.

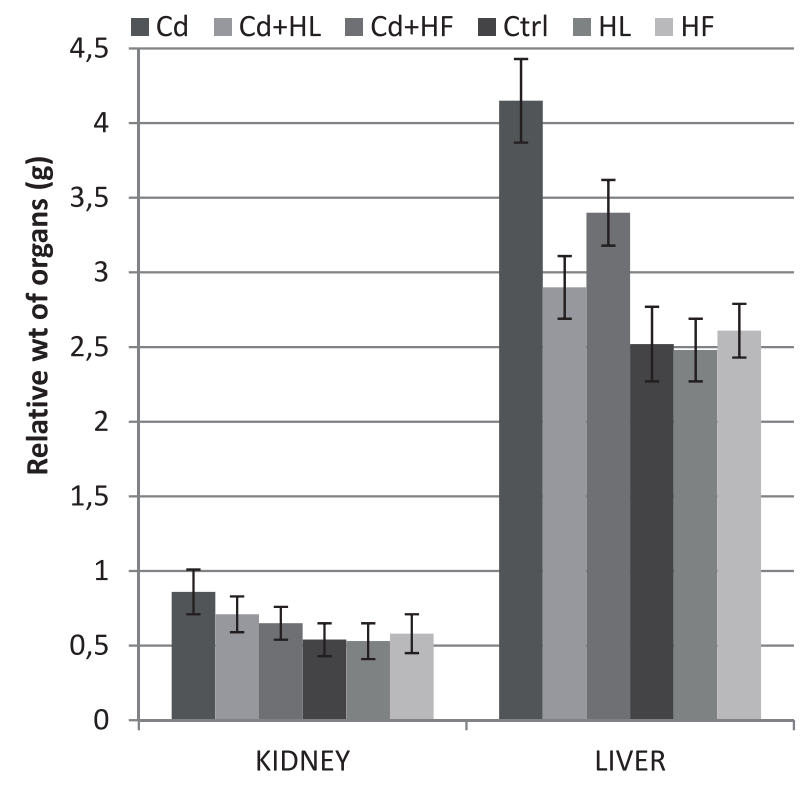

Fig. 2.Comparison of relative weight ( $g$ ) in liver and kidney of male albino rabbits on day 60 of the experiment (mean \pm S.D, $\mathrm{n}=6)$.
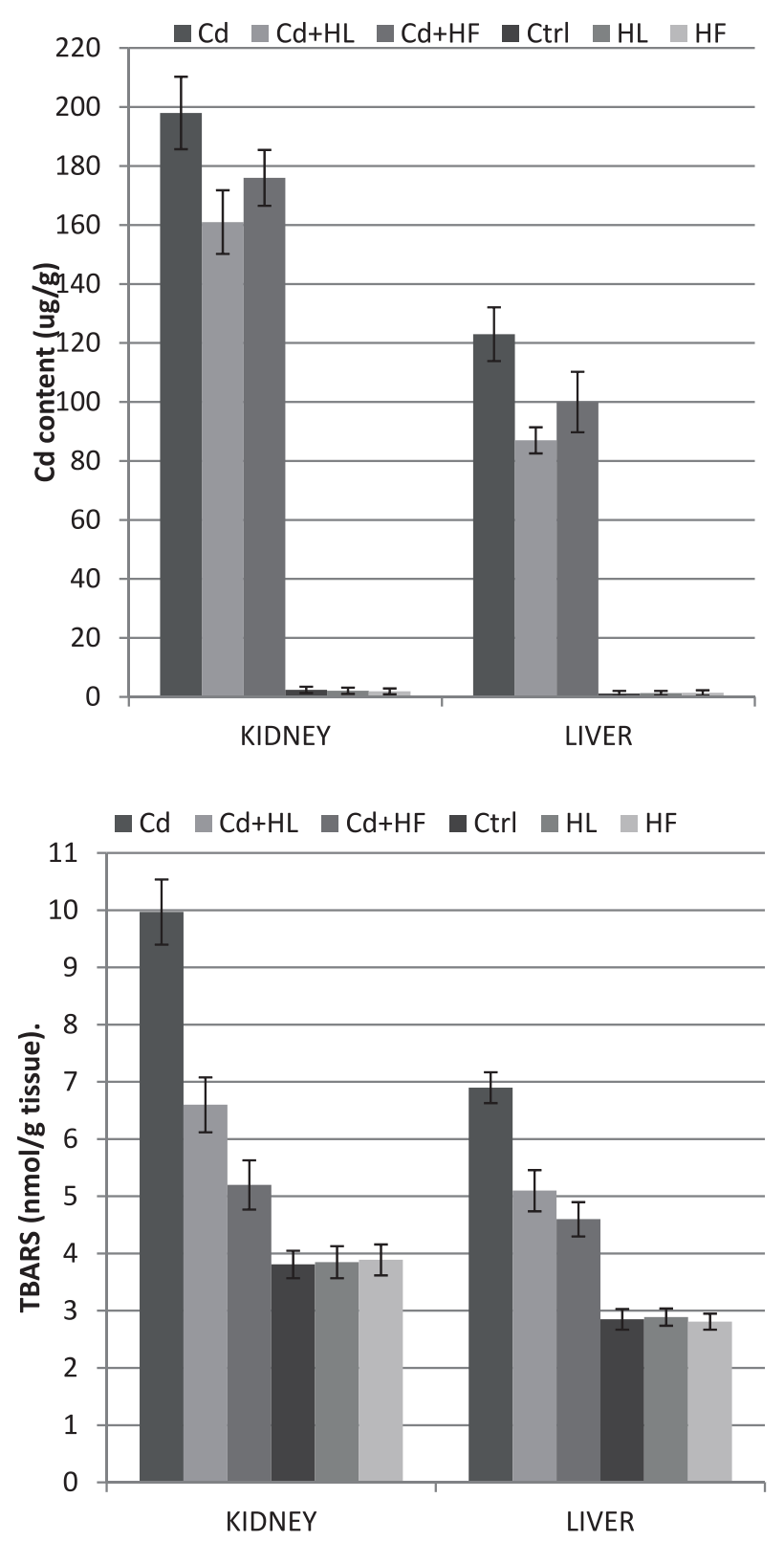

Fig. 3. Comparison of Cd content ( $\mu \mathrm{g} / \mathrm{g}$ tissue), and LPO content (nmol/g tissue) in liver and kidney of male albino rabbits on day 60 of the experiment (mean \pm S.D, $n=6$ ).

\section{Changes in Body Weights of Rabbits}

Fig. 1. shows the variation in body weight among control, Cd-, Cd+HF-, Cd+HL-, HF-, and HL- treated animals during 60 days of this study. Weights were measured carefully on an electronic balance and were recorded after every six days until day 60 . The Cd-treated group showed a decreasing trend in gaining weight from start to the end of the study as compared to control as suggested by [31-32]. These results also revealed that the decreased weight gain due to $\mathrm{Cd}$ exposure existed even with the quantity of food consumption not being disturbed. No change in food consumption habit of animals was observed in the Cd-receiving group. This indicates that this effect of $\mathrm{Cd}$ was intervened by 
Table 2. Values of serum hepatic markers in male albino rabbits at the start and on days $15,30,45$, and 60 of the experiment (mean \pm S.E.M., $\mathrm{n}=6$ ).

\begin{tabular}{|c|c|c|c|c|c|}
\hline \multirow{3}{*}{ Treatment } & \multicolumn{5}{|c|}{ Days } \\
\hline & 0 & 15 & 30 & 45 & 60 \\
\hline & \multicolumn{5}{|c|}{$\operatorname{ALT}(\mathrm{IU} / \mathrm{L})$} \\
\hline $\mathrm{Cd}$ & $52 \pm 4.87 \mathrm{I}$ & $82 \pm 6.03 \mathrm{~F}$ & $136 \pm 6.85 \mathrm{C}$ & $193 \pm 7.53 \mathrm{~B}$ & $218 \pm 7.09 \mathrm{~A}$ \\
\hline $\mathrm{Cd}+\mathrm{HF}$ & $51 \pm 4.34 \mathrm{I}$ & $60 \pm 4.82 \mathrm{HI}$ & $75 \pm 6.54 \mathrm{FG}$ & $99 \pm 8.02 \mathrm{E}$ & $128 \pm 6.23 \mathrm{C}$ \\
\hline $\mathrm{Cd}+\mathrm{HL}$ & $50 \pm 5.09 \mathrm{I}$ & $68 \pm 5.93 \mathrm{GH}$ & $84 \pm 6.72 \mathrm{~F}$ & $113 \pm 7.92 \mathrm{D}$ & $143 \pm 7.32 \mathrm{G}$ \\
\hline $\mathrm{HF}$ & $51 \pm 4.79 \mathrm{I}$ & $53 \pm 5.93 \mathrm{I}$ & $52 \pm 5.18 \mathrm{I}$ & $50 \pm 5.40 \mathrm{I}$ & $55 \pm 4.52 \mathrm{I}$ \\
\hline HL & $54 \pm 5.02 \mathrm{I}$ & $52 \pm 4.94 \mathrm{I}$ & $50 \pm 4.86 \mathrm{I}$ & $53 \pm 4.86 \mathrm{I}$ & $51 \pm 5.37 \mathrm{I}$ \\
\hline Control & $53 \pm 5.22 \mathrm{I}$ & $54 \pm 4.47 \mathrm{I}$ & $51 \pm 5.37 \mathrm{I}$ & $50 \pm 4.38 \mathrm{I}$ & $52 \pm 4.05 \mathrm{I}$ \\
\hline \multicolumn{6}{|c|}{ AST (IU/L) } \\
\hline $\mathrm{Cd}$ & $69 \pm 4.56 \mathrm{I}$ & $104 \pm 6.90 \mathrm{G}$ & $161 \pm 7.90 \mathrm{DE}$ & $219 \pm 7.38 \mathrm{~B}$ & $249 \pm 7.64 \mathrm{~A}$ \\
\hline $\mathrm{Cd}+\mathrm{HF}$ & $72 \pm 4.90 \mathrm{I}$ & $88 \pm 6.47 \mathrm{H}$ & $125 \pm 7.56 \mathrm{~F}$ & $153 \pm 8.10 \mathrm{E}$ & $171 \pm 8.81 \mathrm{CD}$ \\
\hline $\mathrm{Cd}+\mathrm{HL}$ & $71 \pm 3.99 \mathrm{I}$ & $92 \pm 6.80 \mathrm{GH}$ & $131 \pm 8.04 \mathrm{~F}$ & $165 \pm 8.49 \mathrm{DE}$ & $183 \pm 7.62 \mathrm{C}$ \\
\hline $\mathrm{HF}$ & $69 \pm 4.90 \mathrm{I}$ & $70 \pm 5.18 \mathrm{I}$ & $71 \pm 4.86 \mathrm{I}$ & $74 \pm 4.86 \mathrm{I}$ & $72 \pm 5.00 \mathrm{I}$ \\
\hline HL & $68 \pm 4.47 \mathrm{I}$ & $69 \pm 4.90 \mathrm{I}$ & $73 \pm 5.29 \mathrm{I}$ & $70 \pm 4.23 \mathrm{I}$ & $71 \pm 5.18 \mathrm{I}$ \\
\hline Control & $70 \pm 4.24 \mathrm{I}$ & $69 \pm 4.43 \mathrm{I}$ & $74 \pm 6.20 \mathrm{I}$ & $72 \pm 4.69 \mathrm{I}$ & $73 \pm 4.98 \mathrm{I}$ \\
\hline \multicolumn{6}{|c|}{$\operatorname{ALP}(\mathrm{IU} / \mathrm{L})$} \\
\hline $\mathrm{Cd}$ & $114 \pm 4.63 \mathrm{IJ}$ & $151 \pm 6.87 \mathrm{G}$ & $203 \pm 7.16 \mathrm{E}$ & $264 \pm 8.07 \mathrm{~B}$ & $287 \pm 8.32 \mathrm{~A}$ \\
\hline $\mathrm{Cd}+\mathrm{HF}$ & $111 \pm 4.83 \mathrm{~J}$ & $127 \pm 6.23 \mathrm{HI}$ & $161 \pm 7.07 \mathrm{G}$ & $194 \pm 7.92 \mathrm{E}$ & $219 \pm 7.16 \mathrm{D}$ \\
\hline $\mathrm{Cd}+\mathrm{HL}$ & $113 \pm 3.73 \mathrm{~J}$ & $134 \pm 7.07 \mathrm{H}$ & $174 \pm 7.51 \mathrm{~F}$ & $204 \pm 8.46 \mathrm{E}$ & $232 \pm 8.27 \mathrm{C}$ \\
\hline $\mathrm{HF}$ & $110 \pm 4.37 \mathrm{~J}$ & $114 \pm 5.16 \mathrm{IJ}$ & $112 \pm 4.77 \mathrm{~J}$ & $111 \pm 3.83 \mathrm{~J}$ & $113 \pm 4.28 \mathrm{~J}$ \\
\hline HL & $115 \pm 4.02 \mathrm{IJ}$ & $111 \pm 4.36 \mathrm{~J}$ & $113 \pm 4.28 \mathrm{~J}$ & $110 \pm 3.08 \mathrm{~J}$ & $114 \pm 3.72 \mathrm{IJ}$ \\
\hline Control & $112 \pm 4.72 \mathrm{~J}$ & $110 \pm 3.88 \mathrm{~J}$ & $115 \pm 4.58 \mathrm{IJ}$ & $109 \pm 5.08 \mathrm{~J}$ & $111 \pm 5.34 \mathrm{~J}$ \\
\hline \multicolumn{6}{|c|}{ GGT (IU/L) } \\
\hline $\mathrm{Cd}$ & $2.1 \pm 0.26 \mathrm{FG}$ & $2.84 \pm 0.49 \mathrm{DG}$ & $4.29 \pm 0.77 \mathrm{~B}$ & $5.82 \pm 0.78 \mathrm{~A}$ & $6.59 \pm 0.90 \mathrm{~A}$ \\
\hline $\mathrm{Cd}+\mathrm{HF}$ & $2.04 \pm 0.18 \mathrm{FG}$ & $2.23 \pm 0.30 \mathrm{EFG}$ & $2.93 \pm 0.62 \mathrm{DEF}$ & $3.80 \pm 0.87 \mathrm{BCD}$ & $4.31 \pm 0.82 \mathrm{~B}$ \\
\hline $\mathrm{Cd}+\mathrm{HL}$ & $2.07 \pm 0.21 \mathrm{FG}$ & $2.37 \pm 0.41 \mathrm{EFG}$ & $3.13 \pm 0.68 \mathrm{CDE}$ & $4.08 \pm 0.73 \mathrm{BC}$ & $4.68 \pm 0.77 \mathrm{~B}$ \\
\hline HF & $2.10 \pm 0.23 \mathrm{FG}$ & $2.07 \pm 0.24 \mathrm{FG}$ & $2.09 \pm 0.19 \mathrm{FG}$ & $1.96 \pm 0.20 \mathrm{FG}$ & $1.92 \pm 0.24 \mathrm{FG}$ \\
\hline HL & $2.10 \pm 0.29 \mathrm{FG}$ & $2.14 \pm 0.27 \mathrm{FG}$ & $1.99 \pm 0.19 \mathrm{FG}$ & $2.02 \pm 0.17 \mathrm{FG}$ & $2.12 \pm 0.27 \mathrm{FG}$ \\
\hline Control & $2.07 \pm 0.19 \mathrm{FG}$ & $1.98 \pm 0.16 \mathrm{FG}$ & $2.1 \pm 0.14 \mathrm{FG}$ & $2.08 \pm 0.21 \mathrm{FG}$ & $1.94 \pm 0.20 \mathrm{FG}$ \\
\hline \multicolumn{6}{|c|}{ Total Bilirubin (mg/dL) } \\
\hline $\mathrm{Cd}$ & $0.22 \pm 0.03 \mathrm{I}$ & $0.57 \pm 0.05 \mathrm{EF}$ & $0.94 \pm 0.08 \mathrm{D}$ & $1.49 \pm 0.10 \mathrm{~B}$ & $1.71 \pm 0.21 \mathrm{~A}$ \\
\hline $\mathrm{Cd}+\mathrm{HF}$ & $0.23 \pm 0.02 \mathrm{I}$ & $0.39 \pm 0.04 \mathrm{GH}$ & $0.64 \pm 0.05 \mathrm{E}$ & $0.90 \pm 0.09 \mathrm{D}$ & $1.20 \pm 0.15 \mathrm{C}$ \\
\hline $\mathrm{Cd}+\mathrm{HL}$ & $0.24 \pm 0.02 \mathrm{HI}$ & $0.42 \pm 0.03 \mathrm{FG}$ & $0.72 \pm 0,06 \mathrm{E}$ & $0.99 \pm 0.08 \mathrm{D}$ & $1.31 \pm 0,17 \mathrm{C}$ \\
\hline $\mathrm{HF}$ & $0.22 \pm 0.02 \mathrm{I}$ & $0.23 \pm 0.2 \mathrm{I}$ & $0.26 \pm 0.03 \mathrm{HI}$ & $0.22 \pm 0.03 \mathrm{I}$ & $0.25 \pm 0.03 \mathrm{HI}$ \\
\hline HL & $0.23 \pm 0.03 \mathrm{I}$ & $0.24 \pm 0.03 \mathrm{HI}$ & $0.22 \pm 0.03 \mathrm{I}$ & $0.26 \pm 0.03 \mathrm{HI}$ & $0.24 \pm 0.02 \mathrm{HI}$ \\
\hline Control & $0.26 \pm 0.03 \mathrm{HI}$ & $0.23 \pm 0.02 \mathrm{I}$ & $0.25 \pm 0.03 \mathrm{HI}$ & $0.24 \pm 0.03 \mathrm{HI}$ & $0.22 \pm 0.04 \mathrm{I}$ \\
\hline
\end{tabular}

Means sharing similar letter in a row or column (for each parameter) are statistically non-significant $(\mathrm{P}>0.05)$. 
enhancing metabolism rather than disturbing feeding mechanism. However, the incremental trend in gaining weight for $\mathrm{Cd}+\mathrm{HF}$ and $\mathrm{Cd}+\mathrm{HL}$ was seen when compared with the Cd-treated group. The administration of HF and HL to Cd-intoxicated rabbits was capable of protecting against the lowered body weight gain and overall health of rabbits owing to the presence of polyphenols and flavonoids, mainly due to their antioxidant potential that may have led to counteract the damage caused by $\mathrm{Cd}$. The relative weight of kidney and liver showed significant increases in the Cd-receiving group when compared to control as suggested by [33] and as shown in Fig. 2. Values of HF and HL-treated animals were in agreement with the control group and did not show significant variations in weight gain and relative organ weight (kidney, liver) as shown in Figs 1 and 2.

\section{Status of Serum Hepatic Marker Enzymes}

The present study was conducted to assess the potential protective effects of $H$. rosa sinensis on liver toxicity due to oxidative stress caused by $\mathrm{Cd}$ in rabbits for 60 days. Table 2 shows the serum enzyme and total bilirubin of the control, $\mathrm{Cd}, \mathrm{Cd}+\mathrm{HF}, \mathrm{Cd}+\mathrm{HL}, \mathrm{HF}$, and HLtreated adult male rabbits groups. Administration of oral $\mathrm{CdCl}_{2}$ resulted in abnormal values of hepatic functions, in a progressive manner, from day 0 to days $15,30,45$, and 60 of the experiment. This incremental trend was found to be significant $(p<0.05)$ when compared with animals of the control group. In the Cd-treated group, values of serum transaminases such as ALT and AST were increased from 52 to $82,137,193$, and 218, and from 69 to 104 , 161,219 , and $249 \mathrm{IU} / \mathrm{L}$, respectively. An increment in the levels of ALP and GGT from 114 to 151, 203, 264, and 287 , and from 2.13 to $2.84,4.29,5.82$, and $6.59 \mathrm{IU} / \mathrm{L}$ was observed, respectively. Total bilirubin was also augmented from 0.20 to $0.57,0.94,1.47$, and $1.71 \mathrm{mg} / \mathrm{dL}$. Values of all above-mentioned parameters have shown a significant incremental trend $(\mathrm{p}<0.05)$ in Cd-intoxicated rabbits when compared to the control group. Our findings are in close agreement with [34-35] that Cd intoxication significantly raise total bilirubin and liver enzymes in serum. The administration of the ethyl acetate fraction of Hibiscus flowers (200 mg/kg/day) plus Cd (6.1 mg/kg/day) greatly reduced these levels in Hibiscus leaves $(200 \mathrm{mg} / \mathrm{kg} /$ day $)$ plus $\mathrm{Cd}(6.1 \mathrm{mg} / \mathrm{kg} /$ day $)$ at days $15,30,45$, and 60 when compared only to the Cd-receiving group. In $\mathrm{Cd}+\mathrm{HF}$ levels of liver, enzymes such as ALT and AST decreased from 218 to 130 and from 249 to $171 \mathrm{IU} / \mathrm{L}$, whereas in the $\mathrm{Cd}+\mathrm{HL}$ group ALT and AST were decreased from 218 to 141 and from 249 to $183 \mathrm{IU} / \mathrm{L}$ at day 60 , respectively, when compared to the Cd-receiving group. The levels of ALP and GGT in Cd+HF decreased from 287 to 219 and from 6.59 to $4.24 \mathrm{IU} / \mathrm{L}$, whereas in the $\mathrm{Cd}+\mathrm{HL}$ group ALP and GGT decreased from 287 to 232 and from 6.59 to $4.68 \mathrm{IU} / \mathrm{L}$ at day 60 , respectively, when compared to the Cd-receiving group. Total bilirubin also decreased from 1.71 to $1.20 \mathrm{mg} / \mathrm{dL}$ in $\mathrm{Cd}+\mathrm{HF}$, whereas in the $\mathrm{Cd}+\mathrm{HL}$ group it was decreased from 1.71 to $1.31 \mathrm{mg} / \mathrm{dL}$ at day 60 when compared to the Cd-receiving group. Levels of liver enzymes and bilirubin persisted at satisfactory levels in HF and HL groups when compared with the control group as shown in Table 2.

The elevated levels of hepatic enzymes in serum may indicate their leakage from hepatic cells into the bloodstream, thus damaging the hepatic histo-architecture. Higher levels of transaminases and alkaline phosphatase are the decisive factors for identifying liver injury in Cd-intoxicated rabbits as described by [35]. Serum GGT, an enzyme bound to membrane, is the prominent indicator of cellular and tissue injury by lethal substances, and its level is also significantly increased in the Cd-intoxicated group of rabbits. In this study it raised levels of markers of liver injury, recommending that $\mathrm{Cd}$ has caused functional and structural injury to the cellular membranes. It has also augmented the membrane permeability that results in the leakage of liver enzymes into the bloodstream. Total bilirubin was also increased in Cd-treated animals, suggesting that augmented levels of serum bilirubin is also a strong marker of liver dysfunction. Hepatic damage caused by oxidative stress $[29,36]$ can be protected either by employing strong antioxidants that inhibit the generation of free radicals. Several outcomes of a number of studies have also ascertained the protective effects of plant extracts on Cd-induced hepatotoxicity [1, 37-39].

\section{Status of Urine and Serum Renal Marker Enzymes and Serum Proteins}

Table 3 shows the urinary and serum renal enzymes, serum albumin, and total proteins of control, Cd-, $\mathrm{Cd}+\mathrm{HF}-, \mathrm{Cd}+\mathrm{HL}-, \mathrm{HF}-$, and HL-treated adult male rabbit groups. Administering oral $\mathrm{Cd}$ caused unusually elevated renal functions in a progressive manner from day 0 to days $15,30,45$, and 60 of the experiment. The levels of serum creatinine and urea in the Cd-intoxicated group were increased from 1.62 to $2.5,3.2,4.5$, and 5.42, and from 36 to $51,67,79$, and $99 \mathrm{mg} / \mathrm{dL}$, respectively, representing a significant incremental trend $(p<0.05)$ in the Cd-treated group when compared to the control group as described by [34]. The administration of ethyl acetate fraction of Hibiscus flowers (200 mg/kg/day) plus $\mathrm{Cd}(6.1 \mathrm{mg} / \mathrm{kg} /$ day $)$ has greatly reduced these levels compared to the fraction of Hibiscus leaves (200 mg/kg/day) plus Cd (6.1 mg/kg/day) at days 15 , 30,45 , and 60 when compared to only the Cd-receiving group. In $\mathrm{Cd}+\mathrm{HF}$ levels of serum, renal markers such as creatinine and urea were decreased from 5.42 to 2.65 and from 99 to $69 \mathrm{mg} / \mathrm{dL}$, whereas in the $\mathrm{Cd}+\mathrm{HL}$ group these values were decreased from 5.42 to 2.95 and from 99 to $72 \mathrm{mg} / \mathrm{dL}$ at day 60 respectively when compared to the Cd-treated group. The values of urinary creatinine and urea were decreased in the Cd-intoxicated group from 3.1 to $2.2,1.4,1.24$, and 1.08 , and from 134 to $107,87,71$, and $58 \mathrm{mg} / \mathrm{dL}$, respectively, representing a significant decreasing trend $(\mathrm{p}<0.05)$ in the $\mathrm{Cd}$-induced group when compared to the control group as suggested by [40]. The administration of ethyl acetate fraction of Hibiscus 
Table 3. Values of albumin, creatinine, total proteins and urea (serum) and creatinine, and urea (in urine) in male albino rabbits at the start and on days $15,30,45$, and 60 of the experiment (mean \pm S.D, $n=6$ ).

\begin{tabular}{|c|c|c|c|c|c|}
\hline \multirow{2}{*}{$\begin{array}{c}\text { Treatment } \\
\text { Groups }\end{array}$} & \multicolumn{5}{|c|}{ Days } \\
\hline & 0 & 15 & 30 & 45 & 60 \\
\hline \multicolumn{6}{|c|}{ Serum Albumin (mg/dL) } \\
\hline $\mathrm{Cd}$ & $3.77 \pm 0.26 \mathrm{~A}$ & $3.1 \pm 0.22 \mathrm{D}$ & $2.2 \pm 0.15 \mathrm{G}$ & $1.6 \pm 0.14 \mathrm{H}$ & $1.1 \pm 0.09 \mathrm{I}$ \\
\hline $\mathrm{Cd}+\mathrm{HF}$ & $3.7 \pm 0.30 \mathrm{~A}$ & $3.2 \pm 0.24 \mathrm{BCD}$ & $2.9 \pm 0.14 \mathrm{DE}$ & $2.5 \pm 0.19 \mathrm{EFG}$ & $2.2 \pm 0.21 \mathrm{G}$ \\
\hline $\mathrm{Cd}+\mathrm{HL}$ & $3.75 \pm 0.27 \mathrm{~A}$ & $3.13 \pm 0.22 \mathrm{CD}$ & $2.7 \pm 0.15 \mathrm{DEF}$ & $2.3 \pm 0.16 \mathrm{FG}$ & $2.03 \pm 0.20 \mathrm{GH}$ \\
\hline $\mathrm{HF}$ & $3.8 \pm 0.21 \mathrm{~A}$ & $3.64 \pm 0.26 \mathrm{AB}$ & $3.65 \pm 0.21 \mathrm{AB}$ & $3.72 \pm 0.25 \mathrm{~A}$ & $3.70 \pm 0.26 \mathrm{~A}$ \\
\hline HL & $3.68 \pm 0.25 \mathrm{AB}$ & $3.7 \pm 0.29 \mathrm{~A}$ & $3.8 \pm 0.26 \mathrm{~A}$ & $3.65 \pm 0.26 \mathrm{AB}$ & $3.78 \pm 0.29 \mathrm{~A}$ \\
\hline Control & $3.63 \pm 0.23 \mathrm{AB}$ & $3.75 \pm 0.26 \mathrm{~A}$ & $3.69 \pm 0.22 \mathrm{AB}$ & $3.7 \pm 0.24 \mathrm{~A}$ & $3.8 \pm 0.30 \mathrm{~A}$ \\
\hline \multicolumn{6}{|c|}{ Serum Total proteins $(\mathrm{mg} / \mathrm{dL})$} \\
\hline $\mathrm{Cd}$ & $7.5 \pm 0.51 \mathrm{~A}$ & $6.5 \pm 0.33 \mathrm{BCD}$ & $5.3 \pm 0.29 \mathrm{FG}$ & $4.1 \pm 0.26 \mathrm{H}$ & $2.9 \pm 0.18 \mathrm{I}$ \\
\hline $\mathrm{Cd}+\mathrm{HF}$ & $7.45 \pm 0.39 \mathrm{~A}$ & $7.1 \pm 0.49 \mathrm{AB}$ & $6.5 \pm 0.36 \mathrm{BCD}$ & $6.0 \pm 0.3 \mathrm{DEF}$ & $5.2 \pm 0.21 \mathrm{FG}$ \\
\hline $\mathrm{Cd}+\mathrm{HL}$ & $7.55 \pm 0.36 \mathrm{~A}$ & $6.9 \pm 0.24 \mathrm{ABC}$ & $6.2 \pm 0.32 \mathrm{CDE}$ & $5.6 \pm 0.29 \mathrm{EFG}$ & $4.9 \pm 0.24 \mathrm{GH}$ \\
\hline $\mathrm{HF}$ & $7.42 \pm 0.44 \mathrm{~A}$ & $7.38 \pm 0.46 \mathrm{~A}$ & $7.45 \pm 0.52 \mathrm{~A}$ & $7.4 \pm 0.46 \mathrm{~A}$ & $7.53 \pm 0.37 \mathrm{~A}$ \\
\hline $\mathrm{HL}$ & $7.47 \pm 0.40 \mathrm{~A}$ & $7.43 \pm 0.39 \mathrm{~A}$ & $7.53 \pm 0.46 \mathrm{~A}$ & $7.48 \pm 0.45 \mathrm{~A}$ & $7.5 \pm 0.41 \mathrm{~A}$ \\
\hline Control & $7.3 \pm 0.47 \mathrm{AB}$ & $7.4 \pm 0.41 \mathrm{~A}$ & $7.5 \pm 0.57 \mathrm{~A}$ & $7.35 \pm 0.53 \mathrm{AB}$ & $7.6 \pm 0.41 \mathrm{~A}$ \\
\hline \multicolumn{6}{|c|}{ Serum Creatinine $(\mathrm{mg} / \mathrm{dL})$} \\
\hline $\mathrm{Cd}$ & $1.6 \pm 0.24 \mathrm{IJ}$ & $2.5 \pm 0.28 \mathrm{DEF}$ & $3.2 \pm 0.34 \mathrm{C}$ & $4.5 \pm 0.30 \mathrm{~B}$ & $5.45 \pm 0.34 \mathrm{~A}$ \\
\hline $\mathrm{Cd}+\mathrm{HF}$ & $1.55 \pm 0.23 \mathrm{IJ}$ & $1.74 \pm 0.22 \mathrm{HIJ}$ & $2.08 \pm 0.27 \mathrm{FI}$ & $2.32 \pm 0.26 \mathrm{EFG}$ & $2.77 \pm 0.31 \mathrm{CDE}$ \\
\hline $\mathrm{Cd}+\mathrm{HL}$ & $1.58 \pm 0.17 \mathrm{IJ}$ & $1.90 \pm 0.28 \mathrm{GJ}$ & $2.22 \pm 0.21 \mathrm{FGH}$ & $2.51 \pm 0.19 \mathrm{DEF}$ & $2.95 \pm 0.30 \mathrm{CD}$ \\
\hline $\mathrm{HF}$ & $1.6 \pm 0.28 \mathrm{IJ}$ & $1.55 \pm 0.23 \mathrm{IJ}$ & $1.58 \pm 0.19 \mathrm{IJ}$ & $1.62 \pm 0.21 \mathrm{IJ}$ & $1.52 \pm 0.20 \mathrm{~J}$ \\
\hline HL & $1.62 \pm 0.25 \mathrm{IJ}$ & $1.56 \pm 0.22 \mathrm{IJ}$ & $1.57 \pm 0.21 \mathrm{IJ}$ & $1.65 \pm 0.29 \mathrm{IJ}$ & $1.54 \pm 0.21 \mathrm{~J}$ \\
\hline Control & $1.53 \pm 0.22 \mathrm{IJ}$ & $1.58 \pm 0.29 \mathrm{IJ}$ & $1.6 \pm 0.18 \mathrm{IJ}$ & $1.59 \pm 0.17 \mathrm{IJ}$ & $1.62 \pm 0.12 \mathrm{IJ}$ \\
\hline \multicolumn{6}{|c|}{ Serum Urea $(\mathrm{mg} / \mathrm{dL})$} \\
\hline $\mathrm{Cd}$ & $36 \pm 2.83 \mathrm{IJ}$ & $51 \pm 3.46 \mathrm{FG}$ & $67 \pm 4.34 \mathrm{CD}$ & $79 \pm 4.24 \mathrm{~B}$ & $99 \pm 4.47 \mathrm{~A}$ \\
\hline $\mathrm{Cd}+\mathrm{HF}$ & $35.5 \pm 2.88 \mathrm{IJ}$ & $42 \pm 3.03 \mathrm{HI}$ & $51 . \pm 3.58 \mathrm{FG}$ & $60 \pm 3.22 \mathrm{DE}$ & $69 \pm 3.90 \mathrm{C}$ \\
\hline $\mathrm{Cd}+\mathrm{HL}$ & $37 \pm 2.83 \mathrm{HIJ}$ & $44 \pm 2.61 \mathrm{GH}$ & $56 . \pm 3.41 \mathrm{EF}$ & $66 \pm 3.35 \mathrm{CD}$ & $72 \pm 3.74 \mathrm{BC}$ \\
\hline $\mathrm{HF}$ & $37 \pm 3.10 \mathrm{HIJ}$ & $36.5 \pm 2.88 \mathrm{IJ}$ & $33.5 \pm 3.2 \mathrm{IJ}$ & $33 \pm 3.41 \mathrm{~J}$ & $37 \pm 3.29 \mathrm{HIJ}$ \\
\hline HL & $36.6 \pm 2.66 \mathrm{IJ}$ & $37 \pm 3.41 \mathrm{HIJ}$ & $35 \pm 3.35 \mathrm{IJ}$ & $34 \pm 3.41 \mathrm{~J}$ & $36.5 \pm 2.88 \mathrm{IJ}$ \\
\hline Control & $35 \pm 3.35 \mathrm{IJ}$ & $35.5 \pm 2.59 \mathrm{IJ}$ & $37 \pm 3.58 \mathrm{HIJ}$ & $34.5 \pm 3.39 \mathrm{~J}$ & $36 \pm 3.16 \mathrm{IJ}$ \\
\hline \multicolumn{6}{|c|}{ Creatinine in urine $(\mathrm{mg} / \mathrm{dL})$} \\
\hline $\mathrm{Cd}$ & $3.1 \pm 0.26 \mathrm{~A}$ & $2.4 \pm 0.19 \mathrm{~B}$ & $1.8 \pm 0.17 \mathrm{CD}$ & $1.4 \pm 0.14 \mathrm{DE}$ & $1.08 \pm 0.19 \mathrm{E}$ \\
\hline $\mathrm{Cd}+\mathrm{HF}$ & $3.05 \pm 0.24 \mathrm{~A}$ & $2.3 \pm 0.25 \mathrm{~B}$ & $2.1 \pm 0.11 \mathrm{BC}$ & $1.8 \pm 0.19 \mathrm{CD}$ & $1.73 \pm 0.16 \mathrm{CD}$ \\
\hline $\mathrm{Cd}+\mathrm{HL}$ & $3 \pm 0.24 \mathrm{~A}$ & $2.1 \pm 0.14 \mathrm{BC}$ & $1.8 \pm 0.19 \mathrm{CD}$ & $1.6 \pm 0.21 \mathrm{D}$ & $1.68 \pm 0.14 \mathrm{CD}$ \\
\hline $\mathrm{HF}$ & $2.9 \pm 0.26 \mathrm{~A}$ & $3.1 \pm 0.21 \mathrm{~A}$ & $3.08 \pm 0.27 \mathrm{~A}$ & $2.91 \pm 0.21 \mathrm{~A}$ & $2.98 \pm 0.23 \mathrm{~A}$ \\
\hline $\mathrm{HL}$ & $2.93 \pm 0.21 \mathrm{~A}$ & $3.05 \pm 0.24 \mathrm{~A}$ & $3.0 \pm 0.25 \mathrm{~A}$ & $2.92 \pm 0.24 \mathrm{~A}$ & $2.96 \pm 0.20 \mathrm{~A}$ \\
\hline Control & $3.05 \pm 0.18 \mathrm{~A}$ & $3 \pm 0.24 \mathrm{~A}$ & $3.1 \pm 0.28 \mathrm{~A}$ & $3.05 \pm 0.21 \mathrm{~A}$ & $2.95 \pm 0.27 \mathrm{~A}$ \\
\hline
\end{tabular}


Table 3. Continued.

\begin{tabular}{|c|c|c|c|c|c|}
\hline \multicolumn{7}{|c|}{ Urea in urine $(\mathrm{mg} / \mathrm{dL})$} \\
\hline $\mathrm{Cd}$ & $135 \pm 9.4 \mathrm{~A}$ & $107 \pm 8.34 \mathrm{CF}$ & $87 \pm 7.95 \mathrm{GHI}$ & $71 \pm 7.56 \mathrm{IJ}$ & $58 \pm 6.81 \mathrm{~J}$ \\
\hline $\mathrm{Cd}+\mathrm{HF}$ & $134 \pm 9.72 \mathrm{~A}$ & $123 \pm 9.51 \mathrm{ABC}$ & $110 \pm 8.46 \mathrm{CDE}$ & $98 \pm 7.21 \mathrm{DH}$ & $89 \pm 7.75 \mathrm{FI}$ \\
\hline $\mathrm{Cd}+\mathrm{HL}$ & $133 \pm 9.94 \mathrm{~A}$ & $114 \pm 8.88 \mathrm{BCD}$ & $104 \pm 8.74 \mathrm{DG}$ & $92 \pm 7.92 \mathrm{EH}$ & $84 \pm 7.67 \mathrm{HI}$ \\
\hline $\mathrm{HF}$ & $135 \pm 9.36 \mathrm{~A}$ & $136 \pm 9.27 \mathrm{~A}$ & $134 \pm 8.76 \mathrm{~A}$ & $132 \pm 9.13 \mathrm{AB}$ & $135.5 \pm 9.07 \mathrm{~A}$ \\
\hline $\mathrm{HL}$ & $138 \pm 8.76 \mathrm{~A}$ & $134 \pm 9.92 \mathrm{~A}$ & $132 \pm 7.55 \mathrm{AB}$ & $136 \pm 8.29 \mathrm{~A}$ & $137 \pm 8.22 \mathrm{~A}$ \\
\hline Control & $132 \pm 8.94 \mathrm{AB}$ & $137 \pm 9.90 \mathrm{~A}$ & $135 \pm 9.06 \mathrm{~A}$ & $133 \pm 9.61 \mathrm{~A}$ & $139 \pm 9.32 \mathrm{~A}$ \\
\hline
\end{tabular}

Means sharing similar letters in a row or column (for each parameter) are statistically non-significant $(\mathrm{P}>0.05)$.

flowers plus Cd greatly improved these levels over fractions of Hibiscus leaves plus Cd at days 15, 30, 45, and 60 when compared to only the Cd-receiving group. In $\mathrm{Cd}+\mathrm{HF}$ levels of serum, renal markers such as creatinine and urea were increased from 1.08 to 1.74 and from 58 to $89 \mathrm{mg} / \mathrm{dL}$, whereas in the $\mathrm{Cd}+\mathrm{HL}$ group these values were increased from 1.08 to 1.68 and from 58 to $85 \mathrm{mg} / \mathrm{dL}$ at day 60 when compared to the Cd-treated group. Serum levels of albumin and total proteins were also decreased by the Cd-intoxicated group from 3.8 to $3.1,2.2,1.6$, and 1.1 , and from 7.4 to $6.5,5.3,4.1$, and $2.9 \mathrm{mg} / \mathrm{dL}$, respectively, representing a significant decreasing trend $(\mathrm{p}<0.05)$ in the a)

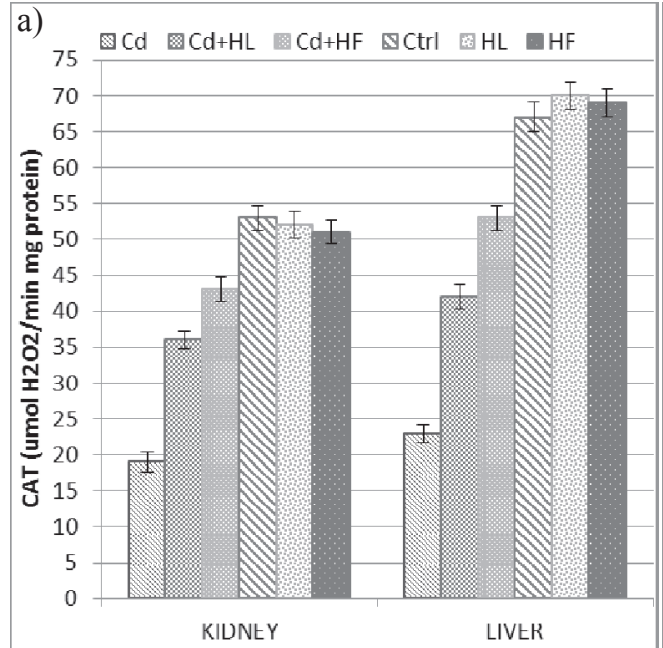

c)

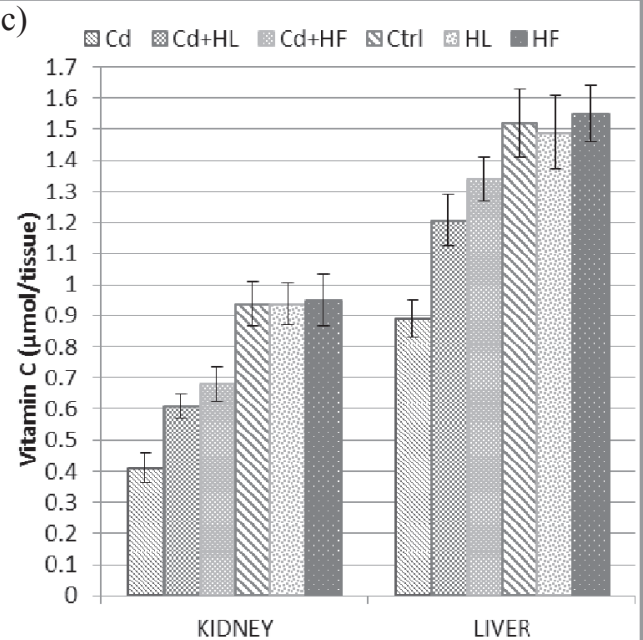

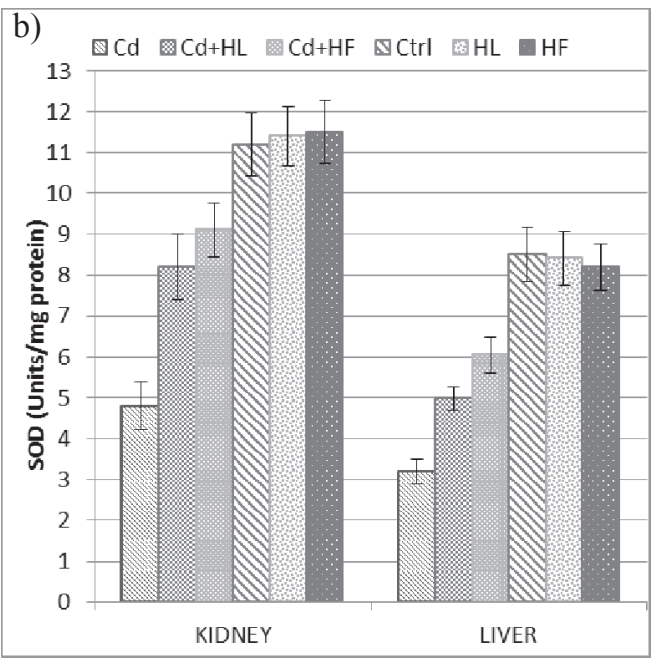

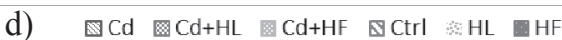

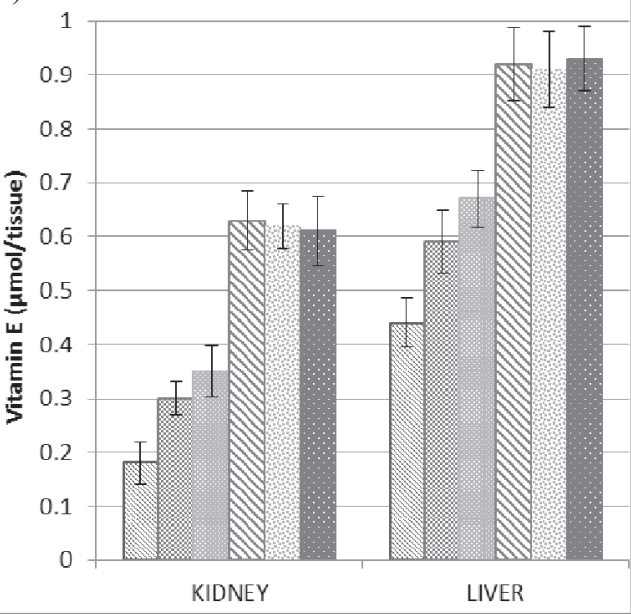

Fig. 4. a) Catalase (CAT, $\mu \mathrm{mol} \mathrm{H}_{2} \mathrm{O}_{2} / \mathrm{min} \mathrm{mg}$ protein), b) superoxide dismutase ( $\mathrm{SOD}$, units/mg protein), c) vitamin $\mathrm{C}$ (ascorbic acid, $\mu \mathrm{mol} / \mathrm{mg}$ tissue), d) and vitamin $\mathrm{E}$ (alpha tocopherol, $\mu \mathrm{mol} / \mathrm{mg}$ tissue) in liver and kidney of male albino rabbits on day 60 of the experiment (mean \pm S.D, $n=6$ ). 
Cd-induced group when compared to the control group, contrary to the results of [41], who revealed an increment in serum albumin in Cd-intoxicated rats. But our findings are in agreement with the results of [37]. Cd plus HF and Cd plus HL significantly restored these levels when compared to the Cd-receiving group. Levels of serum and urine functional enzymes and serum proteins remained at satisfactory levels in HF and HL when compared to the control group as shown in Table 3.

Continued exposure of $\mathrm{Cd}$ may result in damage to various organs and systems, primarily the renal tissue via accumulation in the proximal tubule, initiating generalized re-absorptive dysfunctions. It also creates a great number of non-specific toxicological issues resulting in a decease of renal cells via apoptosis or necrosis. However, it is also proposed that early stages of $\mathrm{Cd}$-induced proximal tubular destruction may implicate much more specific alterations in cell-cell adhesions, autophagy responses, and signaling pathways in cells, which happen well before the inception of necrotic or apoptotic damage [42]. Renal tissues are more vulnerable to damage because of greater perfusion and a large number of combinations are excreted by renal tubular cells. Urea is the major metabolic product obtained from protein breakdown that contains nitrogen. It is wellknown that $\mathrm{Cd}$ impedes the merger of amino acids into proteins, leading to augmented levels of urea. Creatinine is a waste product of creatine phosphate by muscle metabolism and it usually signifies impaired renal function or renal disease. As the kidneys become impaired, the creatinine level in serum will rise due to poor creatinine clearance by the kidneys. Thus, urea and creatinine levels both in serum and urine samples were considered indicators of renal functioning, as hyperuricemia is a renal prognostic factor. The administration of flower and leaf fractions of $H$. rosa sinensis, possessing reasonable antioxidant potential [36], may have protected the renal functions from $\mathrm{Cd}$-induced toxicity by significantly restoring the serum and urine urea and creatinine levels. The present study supports the findings of [43]. Various results suggest that plant extracts may prevent nephrotoxicity by suppressing the oxidative stress caused by Cd [31, 37, 44-46].

\section{Determining Cadmium and LPO Contents in Tissues}

Fig. 3 shows the $\mathrm{Cd}$ and LPO contents in liver and kidney of control, Cd-, Cd+HF-, Cd+HL-, HF-, and HLtreated groups of male adult albino rabbits. Oral $\mathrm{CdCl}_{2}$ has led to an increase in Cd and LPO contents in renal and hepatic tissues. A significant decline in these contents was detected for Cd plus HF and Cd plus HL in kidney and liver samples when these were compared to the control group. Accumulation of $\mathrm{Cd}$ in liver is a notorious consequence of $\mathrm{Cd}$ exposure and it is documented to produce hepatic oxidative damage by increasing peroxidation of membranous lipids, a deleterious process absolutely executed by free radicals. Although free radicals are not generated by $\mathrm{Cd}$ directly, many radicals like superoxide, nitric oxide and hydroxyl are generated indirectly, thus producing harm consistent with oxidative stresses [47], whereas Cd-MT (cadmium-metallothionein) complex made in hepatic cells is released slowly by
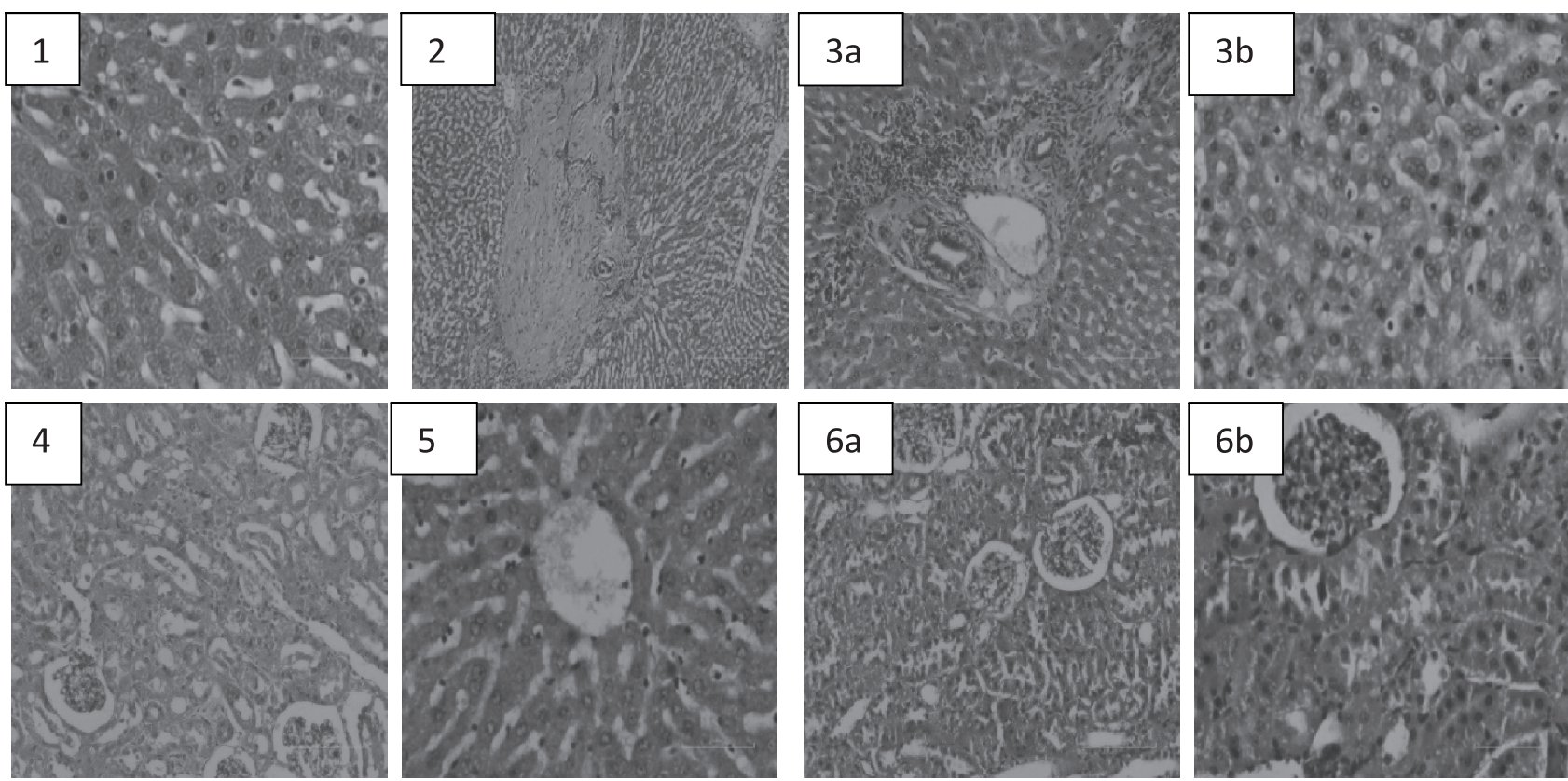

Fig. 5. Microphotographs of: 1) control group rabbit liver showing normal architecture of hepatic cells (400x), 2) $\mathrm{CdCl}_{2}$-intoxicated rabbit liver with increased sinusoidal space and hepatocytes atrophy (400x), 3a) $\mathrm{CdCl}_{2}+\mathrm{HL}$-treated rabbit's liver with near normal cells of liver with few mononuclear cells infiltration (200x), 3b) $\mathrm{CdCl}_{2}+\mathrm{HF}$-treated rabbit's liver with almost normal cells of liver (400x), 4) control group rabbit's kidney showing normal architecture of renal cells (200x), 5b) $\mathrm{CdCl}_{2}$-intoxicated rabbit's kidney showing cellular swelling and glomerular atrophy $(400 \mathrm{x}), 6 \mathrm{a}) \mathrm{CdCl}_{2}+\mathrm{HL}$-treated rabbit with some normal renal tubular cells and some tubules show swelling (200x), and 6b) $\mathrm{CdCl}_{2}+\mathrm{HF}$-treated rabbit with near normal renal cells (400x). 
liver cells and circulates to the kidney tissue. This CdMT complex is dissolved in renal cells, releasing free $\mathrm{Cd}$ that is absorbed by proximal tubules. If renal-MT detoxification and defense systems are incredulous, free $\mathrm{Cd}$ can cause injury to the renal proximal and distal tubules [48], whereas elevated levels of LPO in liver and kidney of $\mathrm{Cd}$-induced rabbits may indicate augmented oxidative stress. MDA levels, being an index of oxidative stress, may enhance peroxidation of membraneous lipids, mechanisms involved in damaging tissues, by changing the antioxidant defense system of tissues [49].

\section{Determination of Antioxidant Enzymes and Vitamins $\mathrm{C}$ and $\mathrm{E}$ in Tissues}

Fig. 4 shows the enzymatic anti-oxidants, i.e., SOD and CAT and non-enzymatic anti-oxidants, i.e., vitamins $\mathrm{C}$ and $\mathrm{E}$ in kidney and liver homogenates of control, Cd-, $\mathrm{Cd}+\mathrm{HF}-, \mathrm{Cd}+\mathrm{HL}-, \mathrm{HF}-$, and HL-treated groups of adult albino rabbits, respectively. The administration of oral $\mathrm{CdCl}_{2}$ has caused abnormal hepatic and renal functions in a progressive manner from days 0 to $15,30,45$, and 60 of the experiment. It resulted in a decline of the levels of SOD and CAT for the Cd-treated group from 11.2 to 4.8 and 53 to 19 for kidney, and from 8.5 to 3.2 and 67 to 23 for liver homogenates, respectively, when compared to the control group. Values of vitamin $\mathrm{C}$ and $\mathrm{E}$ for the Cd-treated group were decreased from 0.94 to 0.41 and 0.63 to 0.18 for kidney, and from 1.52 to 0.89 and 0.92 to 0.44 for liver homogenate, respectively, when compared to the control group. Cd plus $\mathrm{HF}$ and $\mathrm{Cd}$ plus HL has resulted in significant improvement of these values when compared to the Cd-receiving group. Levels of these enzymatic (SOD, CAT) and non-enzymatic (vitamins C and $\mathrm{E}$ ) antioxidants in tissue homogenates persisted at acceptable levels in HF and HL when compared to control rabbits. Enzymatic antioxidants such as SOD and CAT may establish a supportive and defensive group against reactive oxygen species (ROS). Superoxide dismutase, being a metallo-protein, may catalyze the dismutation of superoxide radicals. Catalase, being a hemeprotein, may catalyze the reduction of $\mathrm{H}_{2} \mathrm{O}_{2}$ to $\mathrm{H}_{2} \mathrm{O}$ and $\mathrm{O}_{2}$, thus defending the cells from oxidative destruction by $\mathrm{H}_{2} \mathrm{O}_{2}$ and $\mathrm{OH}^{-}$. The activity of SOD may be decreased either owing to the opposed effect of $\mathrm{Cd}$ with $\mathrm{Cu}$ and $\mathrm{Zn}$, which are considered to be significant metals due to its activity or inactivation of superoxide dismutase by lipid peroxidation induced by $\mathrm{Cd}$. It has been reported that the decline in CAT activity by $\mathrm{Cd}$ might reflect the reduced absorption of Fe, a vital trace metal that is essential for the activity of CAT [34]. Our results are in accordance with $[34,50]$, who also showed that SOD and CAT activities are decreased by $\mathrm{Cd}$ intoxication. The deficiency in the antioxidant defensive system may be considered as an acute event in $\mathrm{Cd}$-induced hepato-renal toxicity. $\mathrm{Cd}$ exposure may be characterized by the depletion of nonenzymatic antioxidants (vitamin $\mathrm{C}$ and $\mathrm{E}$ ) in tissues and in the bloodstream. These are the main non-enzymatic antioxidants that show synergetic effects in scavenging reactive oxygen species or free radicals. Our findings are in accordance with [51-52], who showed that the level of vitamin $\mathrm{C}$ and vitamin $\mathrm{E}$ are significantly reduced during Cd-intoxication, leading to the development of Cdinduced hepatic and renal impairment. The administration of plant extracts in Cd-intoxicated rabbits may protect the enzymatic and non-enzymatic antioxidants by means of either their metal chelation activity or by their antioxidant activities that might reduce the exploitation of these antioxidants, thus reinstating their levels to near normal as described by [53].

\section{Histopathological Studies}

Changes in histopathological patterns in kidneys and liver tissues were assessed in such a manner that a histopathologist, responsible for interpretation, was kept uninformed of the treatment protocols. Studies of liver tissues in the Cd-treated group revealed that per oral $\mathrm{Cd}$ intoxication may have produced severe hepatic damage, including inflammation of the central vein, sinusoidal dilation, inflammatory cell infiltration, necrosis, portal inflammation, and fibrosis when compared to the control group. These changes were reduced in the liver of HF plus $\mathrm{Cd}$ and HL plus Cd rabbits. While studies of kidney tissues in the Cd-treated group revealed that intoxication with orally administered $\mathrm{Cd}$ has caused severe renal damage that includes damage to proximal and distal tubules, hydropic swelling, and degeneration of tubular epithelium when compared to control. Reversal of these changes was observed in $\mathrm{HF}+\mathrm{Cd}$ and $\mathrm{HL}+\mathrm{Cd}$ rabbits. The histo-architecture of liver and kidney was almost normal in HF and HL rabbits as shown in Fig. 5.

\section{Conclusion}

Biochemical markers of liver and kidney function were decreased significantly, whereas albumin and total protein were increased significantly at days 15, 30, 45, and 60 in $\mathrm{Cd}+\mathrm{HF}$ than $\mathrm{Cd}+\mathrm{HL}$ when compared to the Cd-induced group. Moreover, SOD, CAT, and vitamins $\mathrm{C}$ and $\mathrm{E}$ in kidney and liver tissues were increased significantly, whereas $\mathrm{Cd}$ content and LPO were decreased more in $\mathrm{Cd}+\mathrm{HF}$ than $\mathrm{Cd}+\mathrm{HL}$ when compared to $\mathrm{Cd}$-induced rabbits. The histopathological studies for kidney and liver have also supported the idea that $\mathrm{Cd}+\mathrm{HF}$ has lessened the $\mathrm{Cd}$ toxicity in both tissues more than in $\mathrm{Cd}+\mathrm{HL}$ by reversing histo-architecture of said tissues close to normal, thus suggesting that ethyl acetate fractions of Hibiscus rosa sinensis may act as natural protective agents against $\mathrm{Cd}$ toxicity, mainly due to the presence of polyphenols and antioxidant activity.

\section{Acknowledgements}

The corresponding author of this manuscript acknowledges the role of the Higher Education 
Commission in Pakistan (HEC) for providing scholarship under the Indigenous Ph. D. Fellowship Program to undertake this study.

\section{References}

1. PRABU S.M., MUTHUMANI M., SHAGIRTHA K. Protective effect of Piper betle leaf extract against cadmiuminduced oxidative stress and hepatic dysfunction in rats. Saudi Journal of Biological Sciences. 19 (2), 229, 2012.

2. ZANG Y., BOLGER P. Toxic metals: cadmium. Reference Module in Food Science, Encyclopedia of Food Safety. 2, 346, 2014.

3. AL-OLAYAN E.M., EL-KHADRAGY M.F., AREF A.M., OTHMAN M.S., KASSAB R.B., ABDEL MONEIM A.E. The potential protective effect of Physalis peruviana L. against carbon tetrachloride-induced hepatotoxicity in rats is mediated by suppression of oxidative stress and downregulation of MMP-9 expression. Oxidative Medicine and Cellular Longevity. 2014.

4. DEMENESKU J., MIRKOV I., NINKOV M., ALEKSANDROV A.P., ZOLOTAREVSKI L., KATARANOVSKI D., KATARANOVSKI M. Acute cadmium administration to rats exerts both immunosuppressive and proinflammatory effects in spleen. Toxicology. 326, 96, 2014.

5. EL-BOSHY M.E., RISHA E.F., ABDELHAMID F.M., MUBARAK M.S., HADDA T.B. Protective effects of selenium against cadmium induced hematological disturbances, immunosuppressive, oxidative stress and hepatorenal damage in rats. Journal of Trace Elements in Medicine and Biology. 29, 104, 2015.

6. REBELO F.M., CALDAS E.D. Arsenic, lead, mercury and cadmium: Toxicity, levels in breast milk and the risks for breastfed infants. Environmental Research. 151, 671, 2016.

7. JADHAV V., THORAT R., KADAM V., SATHE N. Hibiscus rosa sinensis Linn -"Rudrapuspa": A Review. Journal of Pharmacy Research. 2 (7), 1168, 2009.

8. BEGUM Z., ALI I.Y.S.M. Anti-inflammatory, analgesic and anti-pyretic activities of Hibiscus rosa sinensis Linn and phytochemicals. World Journal of Pharmacy and Pharmaceutical Sciences. 4 (12), 116, 2015.

9. NADE V.S., KANHERE S.V., KAWALE L.A., YADAV A.V. Cognitive enhancing and antioxidant activity of ethyl acetate soluble fraction of the methanol extract of Hibiscus rosa sinensis in scopolamine-induced amnesia. Indian Journal of Pharmacology. 43 (2), 137, 2011.

10. GHAFFAR F.R.A., EL-ELAIMY I.A. In vitro, antioxidant and scavenging activities of Hibiscus rosa sinensis crude extract. Journal of Applied Pharmaceutical Science. 2 (2), 51, 2012.

11. MAGANHA E.G., DA COSTA HALMENSCHLAGER R., ROSA R.M., HENRIQUES J.A.P., DE PAULA RAMOS A.L.L., SAFFI J. Pharmacological evidences for the extracts and secondary metabolites from plants of the genus Hibiscus. Food Chemistry. 118 (1), 1, 2010.

12. SALEM M.Z., PEREZ J., SALEM A. Studies on biological activities and phytochemicals composition of Hibiscus species-A review. Life Science Journal. 11 (5), 1, 2014.

13. PATEL S., ADHAV M. Comparative phytochemical screening of ethanolic extracts (flower and leaf) of morphotypes of Hibiscus Rosa-sinensis Linn. Journal of Pharmacognosy and Phytochemistry. 5 (3), 93, 2016.
14. BHADADA S.V., GOYAL R.K. Effect of flavonoid rich fraction of Tephrosia purpurea (Linn.) Pers. on complications associated with streptozotocin-induced type I diabetes mellitus. Indian Journal of Experimental Biology. 54 457, 2016.

15. SINGLETON V.L., ORTHOFER R., LAMUELARAVENTOS R.M. Analysis of total phenols and other oxidation substrates and antioxidants by means of folinciocalteu reagent. Methods in Enzymology. 299 152, 1999.

16. ZHISHEN J., MENGCHENG T., JIANMING W. The determination of flavonoid contents in mulberry and their scavenging effects on superoxide radicals. Food Chemistry. 64 (4), 555, 1999.

17. PRIETO P., PINEDA M., AGUILAR M. Spectrophotometric quantitation of antioxidant capacity through the formation of a phosphomolybdenum complex: specific application to the determination of vitamin E. Analytical Biochemistry. 269 (2), 337, 1999.

18. SAWANT L., PANDITA N., PRABHAKAR B. Determination of gallic acid in Phyllanthus emblica Linn. dried fruit powder by HPTLC. Journal of Pharmacy and Bioallied Sciences. 2 (2), 105, 2010.

19. MUNN A.J., DAWSON T.J. Forage fibre digestion, rates of feed passage and gut fill in juvenile and adult red kangaroos Macropus rufus Desmarest: why body size matters. Journal of Experimental Biology. 209 (8), 1535, 2006.

20. HUSSAIN N., CHAUDHARY M.N., ANJUM A.A., ABBAS N., KHAN M.N., NADEEM S.M. Investigating the Ameliorative Potential of the Aloe barbadensis Aqueous Fraction on Oxidative Stress Markers and Biochemical Parameters in Cadmium-Intoxicated Rabbits. Polish Journal of Environmental Studies. 25 (6), 2016.

21. BAE J.-W., KIM D.-H., LEE W.-W., KIM H.-Y., SON C.-G. Characterizing the human equivalent dose of herbal medicines in animal toxicity studies. Journal of Ethnopharmacology. 162 1, 2015.

22. PLACER Z.A., CUSHMAN L.L., JOHNSON B.C. Estimation of product of lipid peroxidation (malonyl dialdehyde) in biochemical systems. Analytical Biochemistry. 16 (2), 359, 1966.

23. KAKKAR P., DAS B., VISWANATHAN P. A modified spectrophotometric assay of superoxide dismutase. Indian Journal Biochemistry Biophysics. 21 (2), 130, 1984.

24. AEBI H. Catalase in vitro. Methods in Enzymology. 105 121, 1984.

25. OMAYE S.T., TURNBULL J.D., SAUBERLICH H.E. Selected methods for the determination of ascorbic acid in animal cells, tissues, and fluids. Methods in Enzymology. 62 3, 1979.

26. DESAI I.D. Vitamin E analysis methods for animal tissues. Methods in Enzymology. 105 138, 1984.

27. MAK Y.W., CHUAH L.O., AHMAD R., BHAT R. Antioxidant and antibacterial activities of hibiscus (Hibiscus rosa-sinensis L.) and Cassia (Senna bicapsularis L.) flower extracts. Journal of King Saud University-Science. 25 (4), 275, 2013.

28. PILLAI S.S., MINI S. In vitro antioxidant activities of different solvent fractions from the ethanolic extract of Hibiscus rosa sinensis petals. International Journal of Pharmaceutical Sciences and Research. 5 (9), 3879, 2014.

29. KHAN Z.A., NAQVI S., MUKHTAR A., HUSSAIN Z., SHAHZAD S.A., MANSHA A., AHMAD M., ZAHOOR A. F., BUKHARI I.H., JANJUA M. R.S.A. Antioxidant and antibacterial activities of Hibiscus Rosa-sinensis Linn flower extracts. Pakistan Journal of Pharmaceutical Sciences. 27 (3), 469, 2014. 
30. VONGSAK B., SITHISARN P., MANGMOOL S., THONGPRADITCHOTE S., WONGKRAJANG Y., GRITSANAPAN W. Maximizing total phenolics, total flavonoids contents and antioxidant activity of Moringa oleifera leaf extract by the appropriate extraction method. Industrial Crops and Products. 44 566, 2013.

31. POONTAWEE W., NATAKANKITKUL S., WONGMEKIAT O. Protective Effect of Cleistocalyx nervosum var. paniala Fruit Extract against Oxidative Renal Damage Caused by Cadmium. Molecules. 21 (2), 133, 2016.

32. SAJJAD S., MALIK H., FAROOQ U., RASHID F., NASIM H., TARIQ S., REHMAN S. Cadmium chloride toxicity revisited: effect on certain andrological, endocrinological and biochemical parameters of adult male rabbits. Physiological Research. 63 (4), 505, 2014.

33. CHATER S., DOUKI T., FAVIER A., SAKLY M., ABDELMELEK $H$. Changes in antioxidant status and biochemical parameters after orally cadmium administration in females rats. Acta Biologica Hungarica. 60 (1), 79, 2009.

34. RENUGADEVI J., PRABU S.M. Cadmium-induced hepatotoxicity in rats and the protective effect of naringenin. Experimental and Toxicologic Pathology. 62 (2), 171, 2010.

35. PRABU M.S., SELVARAJAN N., HEMALATHA S., RAMESHKUMAR T. Hepatoprotective effect of Andrographis paniculata against cadmium induced toxicity in male Wistar rats. Toxicology International. 15 (1), 21, 2008.

36. AFIFY A.E.-M.M.R., HASSAN H.M.M. Free radical scavenging activity of three different flowers-Hibiscus rosasinensis, Quisqualis indica and Senna surattensis. Asian Pacific Journal of Tropical Biomedicine. 6 (9), 771, 2016.

37. MOHAMED M., MOHAMED A.H. Protective role of garlic against cadmium toxicity in rats: Clinicopathological and histopathological studies. Egyptain Journal of Comparative Pathology and Clinical Pathology. 22 (3), 2009

38. RAMAMURTHY C., SUBASTRI A., SUYAVARAN A., SUBBAIAH K., VALLURU L., THIRUNAVUKKARASU C. Solanum torvum Swartz. fruit attenuates cadmiuminduced liver and kidney damage through modulation of oxidative stress and glycosylation. Environmental Science and Pollution Research. 23 (8), 7919, 2016.

39. ALLAM A.A., MAODAA S.N., ABO-ELENEEN R., AJAREM J. Protective Effect of Parsley Juice (Petroselinum crispum, Apiaceae) against Cadmium Deleterious Changes in the Developed Albino Mice Newborns (Mus musculus) Brain. Oxidative Medicine and Cellular Longevity. 2016.

40. THANGAPANDIYAN S., SUMEDHAN., MILTONPRABU S. Mentha piperita protects against Cadmium induced oxidative renal damage by restoring antioxidant enzyme activities and suppressing inflammation in rats. International Journal of Pharmacology and Toxicology. 1 17, 2013.
41. GE S., AKHIGBE R. Common onion (Allium cepa) extract reverses cadmium-induced organ toxicity and dyslipidaemia via redox alteration in rats. Pathophysiology. 20 (4), 269, 2013.

42. PROZIALECK W.C., EDWARDS J.R. Mechanisms of cadmium-induced proximal tubule injury: new insights with implications for biomonitoring and therapeutic interventions. Journal of Pharmacology and Experimental Therapeutics. 343 (1), 2, 2012

43. MORALES A., VICENTE-SANCHEZ C., SANDOVAL J.S., EGIDO J., MAYORAL P., ARÉVALO M., FERNANDEZ-TAGARRO M., LÓPEZ-NOVOA J., PEREZ-BARRIOCANAL F. Protective effect of quercetin on experimental chronic cadmium nephrotoxicity in rats is based on its antioxidant properties. Food and Chemical Toxicology. 44 (12), 2092, 2006.

44. KOPEĆ A., SIKORA E., PIĄTKOWSKA E., BORCZAK B., CZECH T. Possible protective role of elderberry fruit lyophilizate against selected effects of cadmium and lead intoxication in Wistar rats. Environmental Science and Pollution Research. 23 (9), 8837, 2016.

45. SURU S.M. Onion and garlic extracts lessen cadmiuminduced nephrotoxicity in rats. Biometals. 21 (6), 623, 2008.

46. SHATI A.A. Effects of Origanum majorana L. on cadmium induced hepatotoxicity and nephrotoxicity in albino rats. Saudi Medical Journal. 32 (8), 797, 2011.

47. STOHS S.J., BAGCHI D., HASSOUN E., BAGCHI M. Oxidative mechanisms in the toxicity of chromium and cadmium ions. Journal of Environmental Pathology, Toxicology and Oncology. 20 (2), 2001.

48. PATRICK L. Toxic metals and antioxidants: part II the role of antioxidants in arsenic and cadmium toxicity.(Toxic Metals Part II). Alternative Medicine Review. 8 (2), 106, 2003.

49. JOVANOVIĆ J.M., NIKOLIĆ R.S., KOCIĆ G.M., KRSTIĆ, N.S., KRSMANOVIĆ M.M. Glutathione protects liver and kidney tissue from cadmium-and lead-provoked lipid peroxidation. Journal of Serbian Chemical Society. $\mathbf{7 8}$ 197, 2013.

50. WAISBERG M., JOSEPH P., HALE B., BEYERSMANN D. Molecular and cellular mechanisms of cadmium carcinogenesis. Toxicology. 192 (2), 95, 2003.

51. SK U.H., BHATTACHARYA S. Prevention of cadmium induced lipid peroxidation, depletion of some antioxidative enzymes and glutathione by a series of novel organoselenocyanates. Environmental Toxicology and Pharmacology. 22 (3), 298, 2006.

52. VALKO M., MORRIS H., CRONIN M. Metals, toxicity and oxidative stress. Current medicinal chemistry. 12 (10), 1161, 2005.

53. SAKR S., BAYOMY M., EL-MORSY A. Rosemary extract ameliorates cadmium-induced histological changes and oxidative damage in the liver of albino rat. The Journal of Basic \& Applied Zoology. 71 1, 2015. 